\title{
КАБИНЕТ ПАРЛАМЕНТСКОГО МЕНЬШИНСТВА: СТАТУС И ДЕЯТЕЛЬНОСТЬ НА ПРИМЕРЕ КАНАДЫ
}

\begin{abstract}
Аннотация: Предметом изучения в настоящей статье являются статус и основные направления деятельности специифического вида правительства - правительства парламентского меньшинства на примерах Канады второй половины ХХ и начала ХХІ веков. В том числе рассматривается источники правового регулирования статуса и деятельности кабинета меньшинства. Автор исследует общее и особенное в его отношениях с нижней палатой парламента и оппозиционными партиями, прослеживает реализацию правительственных приоритетов в экономической и социальной сфере. Анализу подвергнуть также деятельность кабинета меньшинства по поддержанию национально-государственного единства федерации. Раскрывается специфика топливно-энергетической стратегии Оттавы. Обращено внимание на трудности государственного управления в децентрализованной федерации. В методологическом плане автор придерживается позиций системно-комплексного и сравнительного анализа. В статье в известной степени использован также метод исторического анализа. Ставщие в нашей научной и публицистической литературе шаблонными мнения о органической слабости и неэффективности кабинета парламентского меньшинства являются ложными. Повышенная сложсность руководства парламентским государством, особенно в условиях отсутствия у кабинета устойчивого большинства в нижней палате парламента, служит стимулом повышения уровня управленческого искусства правительства.

Abstract: The subject of this article is the status and main directions of the work of a specific type of government-a minority cabinet on the example of Canada's parliamentary system in the end of the 20th, beginning of the $21^{\text {st }}$ century. The author also reviews the sources of the legal regulation of the status and the work of the minority cabinet. Its relations with the lower house and the opposition parties, as well as the implementation of the government priorities within the economic and social areas are being researched. The work of the cabinet aimed at supporting the national state unity of the federation is also being analyzed. The specific of the fuel and energy strategy of Ottawa is revealed. The author emphasized the difficulties of state government and decentralized federation. The opinions established within our scientific and publicistic literature about the inherent weakness and non-effectiveness of the minority cabinet are false. The higher complexity of managing the parliamentary state, precisely under the conditions when the sustained majority is absent in the lower house, stimulates the increase of the level of management skill of the government.
\end{abstract}

Ключевые слова: Парламент, кабинет, меньшинство, большинство, партии, конституционные конвениии, вотум недоверия, статуты, резолюиии, делегированное законодательство.

Keywords: Parliament, cabinet, minority, majority, parties, constitutional conventions, motion of no confidence, statute, resolutions, delegated legislation.

отечественной государствоведческой литературе существует заметный пробел. Речь идет о статусе и эффективности правительств парламентского меньшинства. Такие правительства знакомы конституционной практике приблизительно 20 стран мира, в том числе более чем половине государств «семерки»- Великобритании, Германии, Италии, Канаде, Японии. Кабинеты меньшинства стали обычаем в Скандинавских странах, Индии, Австралии.

Издаваемые в нашей стране учебные и монографические публикации отводят правительствам меньшинства по нескольку строк, подчеркивая их неустойчивость и недолговечность ${ }^{1}$. Негативное отношение проистекает из нашей внутренней настроенности на предсказуемость и стабильность, которых кабинет меньшинства не может обещать по определению. Другая причина - критическое восприятие всего, что связано с парламентом и его верховенством, практика которого вызвала к жизни рассматриваемый феномен, чуждый всем остальным государственным формам.

То, что кабинеты парламентского меньшинства (как и большинства) имеют уязвимые стороны, не нуждается в доказательствах. Их не зря ассоциируют с зависимостью планов и действий исполнительной власти от оппозиционных партий, чересполосицей вотумов доверия и недоверия, внеочередными выборами. Формирование таких кабинетов

${ }^{1}$ См., например: Сравнительное конституционное право. Монография. Отв. ред. Чиркин В.Е. - М.: Манускрипт, 2002. С. 624 - 625. сопровождается снижением курса биржевых акций. Средний срок пребывания кабинетов меньшинства у власти закономерно не превышает полутора-двух лет. Политические обозреватели называют их «кошмаром парламентского правления». Но поскольку кабинеты меньшинства превратились в неотъемлемую часть конституционной практики нескольких десятков стран, их недостатки целесообразно анализировать в комплексе с достоинствами.

Правовую базу кабинета меньшинства образуют правовые прецеденты и конституционные конвенции. Они делают ненужным регулирование статуса и деятельности правительства нормами позитивного (в данном случае статутного) права. Политическая предпосылка образования такого кабинета - невозможность образования однопартийного парламентского большинства. Кабинету приходится заключать соглашения о коалиция $\mathrm{x}^{2}$ с малыми парламентскими

\footnotetext{
2 В парламентских государствах необходимо различать правительственные и парламентские коалиции. Первые из них являются официальными и сопровождаются распределением министерских постов между парламентскими партиями. Все партии - участники таких коалиций становятся тем самым ответственными за деятельность правительства. Правительственные коалиции (двух- или многопартийные правительства) характерны главным образом для парламентских стран Европы. Коалиционным является, в частности, кабинет Д.Камерона в Великобритании, стоящий у власти с 2010г. Парламентские коалиции могут быть как официальными, организационно оформленными, так и неофициальными. Деятели малых партий-членов парламентской
} 
DOI: $10.7256 / 1811-9018.2014 .12 .13431$

При цитировании этой статьи сноска на doi обязательна

\section{Право и политика $12(180) \cdot 2014$}

партиями, от которых зависит, какая из крупных партий получит право на реализацию исполнительной власти.

Среди стран, в которых возникли кабинеты меньшинства, видное место принадлежит Канаде, где они формируются с 1921г. Такие кабинеты управляли страной на протяжении почти четверти столетия. Некоторые премьер-министры Л.Пирсон (1963-1968 гг.), Дж.Кларк (1979-1980 гг.) и П.Мартин (2004-2006гг.) фигурируют в конституционной истории страны с репутацией «премьеров меньшинства». Другим, как например П.Трюдо (1968-1979 и 1980-1984гг.), удавалось преобразовывать кабинеты меньшинства в правительства большинства.

Если в Канаде и в других парламентских демократиях легитимность кабинетов меньшинства не вызывала сомнений, то оценки их управленческого потенциала первоначально не были высокими. Осуществленные первыми кабинетами меньшинства меры трудно было назвать значительными. Так, кабинет М.Кинга (1921-1930гг.) уменьшил таможенные пошлины и учредил незначительные по размеру пенсии. Положение стало меняться, начиная с кабинета Л.Пирсона, результативность действий которого была на порядок выше. Он добился принятия статутов о национальном флаге, об отмене смертной казни и об ограничении доли иностранного капитала в «ключевых отраслях» - банковском и страховом деле, на радио и телевидении.

Действия последнего во времени кабинета меньшинства С.Харпера (2006-2011гг.) свелись к выборочному снижению ставок прямого налогообложения и к проведению парламентской резолюции о признании существования в Квебеке «самобытного народа». Резолюция подтвердила право франкоязычного Квебека на языковую и культурную самобытность и на самостоятельную иммиграционную политику. Оценки данной меры правительства неоднозначны. Иногда в ней видят неоправданную уступку квебекским сепаратистам. Но при этом упускают из виду, что резолюция Парламента, не имеющая силы акта статутного права и тем более - конституционной поправки, может быть безболезненно отменена другой резолюцией ${ }^{3}$. Резолюция, подтверждающая «специальный статус» Квебека в рамках Канады, призвана выполнять функцию дополнительного инструмента поддержания единства и целостности федерации ${ }^{4}$.

Исследователи сходятся, однако, на том, что из всех кабинетов меньшинства, стоявших у власти в Канаде, наи-

коалиции в состав правительства не входят. Пребывание в таких коалициях обязывает малые парламентские партии только поддерживать правящую партию при голосованиях по законопроектам и вотумам доверия или недоверия. За деятельность правительства они ответственности не несут и сохраняют право критики партнера. В настоящей статье речь пойдет о парламентских коалициях, свойственных Канаде (а также Индии и Японии).

${ }^{3}$ Подробнее об источниках регулирования в странах «общего права» см.: Богдановская И.Ю. Закон в английском праве. М.: Наука, 1987; ее же. Прецедентное право. М.: Наука, 1993.

${ }^{4}$ Подробнее о современном статусе Квебека см.: Данилов С.Ю. Правовое регулирование «специального статуса» субъекта федерации. Дифференциация права на примере Квебека // Право. Журнал Высшей школы экономики. 2012. №2; его же. Эволюция канадского федерализма. М.: Издательский дом НИУ ВШЭ, 2012. больший конструктивный вклад в развитие страны внесло правительство П.Трюдо (1972 - 1974 гг.).

Исход очередных выборов лишил Либеральную партию парламентского большинства: в Палате общин она сохранила 109 мест против 155 у оппозиционных партий. Партия официальной оппозиции - Консервативная (107 мест) со ссылкой на прецеденты требовала передать ей власть без новых выборов. Но контроль над соотношением сил в Палате был у социалистов (Новой демократической партии - НДП), коалицию с которыми консерваторы исключали «по принципиальным соображениям». Итогом стало образование парламентской коалиции социалистов и прагматически настроенных либералов. Либералы обеспечили коалиции управленческие и финансовые ресурсы исполнительной власти, а НДП - рабочее большинство в Палате общин и реформистские импульсы снизу.

Готовность коалиции к реформам нашла выражение в последовательном наращивании социальных расходов и развитии программ социальной защиты индивидуума. Размеры выплат на детей кабинет меньшинства увеличил в три раза, так что «детский капитал» стал весомым подспорьем большинству канадских семей. Парламентские статуты, регулирующие пенсионное законодательство, были дополнены положениями о повышении пенсий на $15 \%$ и об их ежеквартальной антиинфляционной индексации, что сделало канадских пенсионеров наиболее защищенной от роста розничных цен социальной группой. Около 1млн. низкооплачиваемых граждан было освобождено от федеральных налогов. Остальным группам населения были сокращены ставки подоходного налога. Снижены были ставки особенно непопулярных косвенных налогов, которыми облагалась продажа товаров широкого потребления - одежды, обуви, строительных материалов.

Из повестки Палаты общин был изъят билль о лишении права на социальные пособия лиц, уволенных «за плохое исполнение обязанностей» или уволившихся «без должных оснований» (критерием было мнение работодателя). Вместо него Палата голосами либералов и новых демократов приняла билль о временном («пока Парламент не постановит иного») снятии ограничений на финансирование пособий безработным. Размеры пособий были увеличены, «сроки ожидания» перед их получением уменьшены вдвое.

В плане борьбы с ростом цен правительство меньшинства отклонило требования официальной оппозиции о невмешательстве государства в процессы ценообразования («в рыночной экономике цены не бывают завышенными»), равно как и диаметрально противоположную идею НДП о немедленном замораживании «неоправданно завышенных» потребительских цен. Кабинет взял курс на выборочное регулирование ценообразования, установив резолюцией Парламента контроль над ценами «на самые массовые продукты питания». К таковым после дебатов в специальном комитете Палаты общин были причислены хлеб, молоко, яйца и мясо недорогих сортов. Временными рамками контрольной программы были названы сроки полномочий Палаты данного созыва. Производителям и торговцам, воздерживавшимся от увеличения цен, резолюция гарантировала право на правительственные субсидии, компенсировавшие среднестатистическую упущенную выгоду. В Министерстве потребителей и корпораций по настоянию социалистов было образовано 
Бюро контроля над продовольственными ценами, которое расследовало причины повышения потребительских цен и предавало соответствующие факты гласности. В итоге большинство предпринимателей приняло участие в программе добровольного контроля.

В вопросе о повышении занятости кабинет всецело следовал призывам и рекомендациям социалистов. Было введено «свободное финансирование» общественных работ и в течение года трудоустроено свыше половины официально зарегистрированной резервной армии труда. Таких впечатляющих результатов борьбы с безработицей страна не знала ни раньше, ни позже.

Актами делегированного законодательства ${ }^{5}$ была демократизирована федеральная жилищная политика: ограничены размеры арендной платы в федеральном жилом фонде и введено льготное кредитование покупателей квартир и жильцов с невысокими доходами. Правительственная Национальная корпорация жилищного строительства за полтора года в несколько раз увеличила количество вводимых в эксплуатацию единиц жилья - квартир и частных домов. Заметно ускорилась расчистка трущобных кварталов в канадских мегаполисах. По масштабам строительства и ввода недорогого жилья Канада при правительстве меньшинства впервые превзошла Соединенные Штаты с их гораздо более обширным человеческим и экономическим потенциалом. Это позволило надолго и в значительной мере замедлить рост цен и арендной платы в жилищном секторе.

Чтобы не лишиться базы поддержки в предпринимательском сообществе, кабинет меньшинства вопреки возражениям НДП сделал весомые уступки национальному капиталу. Ставку банковского процента кабинет снизил в полтора раза, существенно облегчив таким образом условия кредитования малого и среднего предпринимательства. Кабинет внес в Палату общин билли об амортизационных льготах бизнеса в целом и о снижении на один год основной ставки налога с фирм обрабатывающей промышленности. Консерваторы, тесно связанные с бизнесом, были вынуждены в данных вопросах голосовать вместе с правительством. Голосование новых демократов «против» не имело правовых последствий: оба билля стали статутами, а правительство осталось у власти.

В Парламенте правительство меньшинства, таким образом, попеременно блокировалось с партиями, которые занимали во многих вопросах взаимоисключающие позиции. Оно заставило работать на себя даже партию официальной оппозиции. Свой курс правительство проводило под конструктивным лозунгом:«Никто не проигрывает - все выигрывают».

Разумные коррективы были внесены в мало популярную ранее политику региональной помощи, непропорционально большая доля которой полагалась «болевой точке федерации» - Квебеку, что не могло не раздражать англоязычную (преобладающую) часть электората. Актами делегированного законодательства кабинет меньшинства перераспределил потоки региональных кредитов и грантов так, чтобы доля провинций-реципиентов приблизительно совпала с их долей в населении, но с перевесом в пользу стагнационных

${ }^{5}$ Об этом источнике правового регулирования см.: Богдановская И.Ю. Делегированные акты как вторичный источник права/ Право. Журнал Высшей школы экономики. 2013. №3. С.36 - 48.
Атлантических провинций. Положение ведущего в пересчете на душу населения реципиента вместо франкоязычного на $80 \%$ Квебека занял англоязычный на $65 \%$ Нью-Брансуик.

Политику региональной помощи кабинет модернизировал и в отраслевом отношении. Министерство регионального развития (МРР) стало выделять преобладающую часть ассигнований не филиалам крупных промышленных корпораций, как ранее, а малому и среднему национальному предпринимательству, которое занято в менее подверженной колебаниям хозяйственных циклов сфере инфраструктурытранспорта, связи, сферы обслуживания. Кроме того, более половины служащих МРР было переведено из столицы в его региональные отделения.

Результаты «смены вех» нашли выражение в благоустройстве периферийных районов англоязычной Канады, в сокращении оттока молодежи с этих территорий и в торможении расползания индустриальной экономики по территории федерации. Власти и население отдаленных регионов стали видеть в МРР (хотя и не в федеральной власти в целом) ценного партнера. Политика сглаживания региональных диспропорций, декларированная ранее многими правительствами большинства, при кабинете меньшинства обрела четкие контуры и принесла близкие к оптимальным результаты, что не могло не пойти на пользу поддержанию единства федерации.

В проводимой с 1960-х годов политике двух официальных языков, вызывавшей возражения англоканадцев и не успокаивавшей квебекских сепаратистов, кабинет частично уступил требованиям англоязычного большинства. Принудительное обучение англоязычных государственных служащих французскому языку было прекращено. Из актов делегированного законодательства были устранены положения об увольнении с государственной службы ввиду незнания второго официального языка. Перевод всех звеньев федерального государственного аппарата на всеобъемлющий режим двуязычия был отложен на неопределенное время.

В русле развития правового государства и политической демократии двухпартийная коалиция нашла возможности сделать два серьезных шага. НДП настаивала на статутном запрете совмещения извлечения частной прибыли с политической деятельностью. Но более половины депутатов, включая многих либералов, отказалось его поддержать. Тогда премьер-министр, воспользовавшись конституционными конвенциями о полномочиях главы правительства, провел проект через кабинет в качестве акта делегированного законодательства. Правило «О конфликте интересов» запретило министрам и государственным служащим запрещалось иметь любые «экономические интересы» ${ }^{6}$, кроме семейных состояний. Пакеты акций предписывалось продать, переоформить на других лиц или поместить в правительственный «слепой фонд». Было также запрещено оказание членами правительства и государственными служащими «благоволения» частным фирмам, с которыми индивидуумы когда-либо ранее были связаны ${ }^{7}$.

\footnotetext{
${ }^{6}$ По нашей терминологии - «любая другая оплачиваемая деятельность».

${ }^{7}$ Вне зависимости от того, был ли индивидуум ранее главой фирмы, членом ее директорского или наблюдательного совета, менеджером, рядовым работником, держателем пакета акций или только заключал с фирмой контракты.
} 
DOI: $10.7256 / 1811-9018.2014 .12 .13431$

При цитировании этой статьи сноска на doi обязательна

\section{Право и политика $12(180) \cdot 2014$}

В отношении рядовых депутатов продолжали действовать конституционные конвенции, разрешающие совмещать депутатские обязанности с юридической ${ }^{8}$ и медицинской практикой (однако не с преподаванием, научной или творческой работой $)^{9}$.

Еще одним нововведением в конституционно-правовой сфере стало утверждение Парламентом билля «Об избирательных расходах», варианты которого ранее безрезультатно обсуждались в комитетах палат и в СМИ не менее десяти лет.

Статут 1974 г. сделал предметом детального правового регулирования ряд аспектов деятельности политических партий. Обязательным условием их участия в парламентских выборах стала регистрация перед каждой избирательной кампанией в Национальном избирательном ведомстве (НИБ). Далее, статут установил лимиты партийных доходов и расходов во время предвыборных кампаний, определил круг лиц, не наделенных правом на предвыборные взносы в партийные фонды. Партиям и их кандидатам статут вменил в обязанность подавать после выборов подробные финансовые отчеты, подтвержденные необходимой документацией, а НИБ - обеспечивать публикацию этих отчетов.

Законодатель предусмотрел набор административных и уголовных санкций против нарушителей положений статута. Административные санкции, налагаемые НИБ и включающие лишение партий и кандидатов права на установленные статутом льготы ${ }^{10}$, не могут быть оспорены в суде. Уголовные санкции - денежные штрафы до 25.000 кан.долл. и /или лишение свободы по приговору суда на срок до пяти лет, причем уголовному преследованию могут быть подвергнуты как депутаты и министры, баллотирующиеся на выборах, так и лица, не вовлеченные непосредственно в избирательный процесс: президенты и вице-президенты партий, партийные секретари, казначеи, финансовые агенты и др.

Указанным актом статутного права внедрено частичное государственное финансирование выборов. Федеральная казна стала возмещать не нарушающим законодательства партиям и кандидатам значительную часть их предвыборных расходов. Получают безналичные компенсации (налоговые вычеты) физические и юридические лица, делающие предвыборные взносы в фонды партий и кандидатов. Размеры компенсаций обратно пропорциональны размерам взносов.

Данный закон приходится считать самым популярным во всей правовой системе страны актом статутного права: его рейтинг на опросах составил $86 \%$. Его принятие покончило с положением, при котором политические партии действовали в «правовом вакууме» и не могли поэтому привлекаться к юридической ответственности, а их финансы считались их внутренним делом. Партии и кандидаты стали менее зависимыми от корпораций и самых высокодоходных категорий населения ${ }^{11}$.

\footnotetext{
${ }^{8}$ Точнее, с профессией барристера и солиситора.

${ }^{9}$ Campbell D., ed. Legal Aspects of Doing Business in Canada. Minneapolis, 1997. P.120-122.

${ }^{10}$ Они включали, в частности, право партий на доступ к распределению бесплатного эфирного времени на государственных радио- и телеканалах.

${ }^{11}$ Hodgins B. Where Constitution and Economy Meets in Canada. Toronto, 1997. - P. 16,18.
}

Большинство рассмотренных выше действий правительства меньшинства могло быть только дорогостоящим. Бюджетно-финансовые последствия правления кабинета были позже охарактеризованы экономистами как «взрыв федеральных расходов». Объем бюджетных ассигнований стал возрастать на 20-25\% ежегодно. В поисках средств кабинет по требованию НДП отказался от практики отсрочек возвращения корпорациями федеральных кредитов. Затем были повышены ставки ряда налогов с высокооплачиваемых слоев. Оздоровлению финансов это не помогло ввиду опережающего роста социальных расходов. Бюджетный дефицит, незначительный при правительствах большинства, значительно возрос. Кабинету пришлось санкционировать наращивание денежной массы: на первом году его деятельности эмиссия составила $15 \%$, а годом позже $-28 \%{ }^{12}$.

Положение правительства должен был ухудшить глобальный энергетический кризис 1973г., который поставил под сомнение все компоненты энергетической политики Канады: снабжение США западноканадской нефтью, а Канады-импортной; защищенное Конституцией монопольное право провинциальной власти на арендные платежи энергетического сектора ${ }^{13}$; налоговые льготы нефтегазового бизнеса; невмешательство федеральной власти в налогообложение и ценообразование в отрасли.

В противоположность правительствам многих стран канадский кабинет меньшинства не был захвачен энергетическим кризисом врасплох. Секретариат премьер-министра (СПМ) спрогнозировал наступление кризиса за четыре месяца до его начала и разработал проекты контрмер. По наметкам СПМ на бюджетные средства вовремя были, оборудованы дополнительные хранилища энергоносителей, увеличены субсидии на импорт горючего, начата многократно откладывавшаяся прокладка трансканадского трубопровода.

Реагируя на скачок нефтяных цен, правительство меньшинства стало действовать вразрез с волей и интересами нефтегазовых ТНК, правительств нефтедобывающих провинций и правящих кругов США. Во-первых, оно еще до начала кризиса стало отклонять все предложения и требования об увеличении экспорта нефти и газа в Штаты и взяло курс на его свертывание. Во-вторых, правительство совершило беспрецедентный в масштабах Запада шаг: оно в условиях мирного времени распоряжением Министерства энергетики заморозило внутренние цены на нефть и газ. При этом на территории нефтедобывающих провинций цены были занижены. В-третьих, замораживание не распространили на экспортные цены, которые продолжали расти вместе с мировыми. Так была создана гибкая и выгодная огромному большинству канадцев система «двойных цен» ${ }^{14}$.

\footnotetext{
${ }^{12}$ См. подробнее: Laforest G., ed. Reconciling the Solitudes. Essays on Canadian Federalism and Nationalism. Montreal, 2003; Savoie D. Public Spending in Canada. Toronto, 2000; Stevenson G. Unfulfilled Union. Canadian Federalism and National Unity. Toronto, 2004.

${ }^{13}$ Оно закреплено статьей 92-й Конституции, которая относит эксплуатацию и продажу природных ресурсов к сфере исключительной субъектной компетенции (Canada. Department of Justice. The Constitution Acts 1867 to 1982 . Ottawa, 2001. P.29, 30).

${ }^{14}$ Beigie C., Hero S., eds. Natural Resources in US - Canadian Relations. Vol.2. Boulder (Col.), 1990. P. 259-260.
} 
Государственные институты и правовые системы

В-четвертых, правительство использовало принципиально новое, не примененное даже в военное время средство регулирования рынка нефтепродуктов. Их экспорт был обложен федеральной пошлиной, размеры которой Парламент в течение года увеличивал специальными резолюциями 16 раз сообразно с ростом мировых цен на энергоносители ${ }^{15}$.

Наконец, федеральная власть стала выплачивать нефтепотребляющим провинциям Центральной Канады субсидии, призванные компенсировать урон, причиненный этим субъектам недостатком нефтепродуктов.

В ходе борьбы с энергетическим кризисом новые демократы потребовали национализировать канадский филиал одной из нефтегазовых ТНК с его преобразованием в государственную корпорацию. Отрицательный ответ означал бы падение кабинета и внеочередные выборы. Согласие с предложением социалистов вовлекло бы правительство в прямую конфронтацию с транснациональным бизнесом, питающим канадскую экономику современной технологией и квалифицированными кадрами. В таких условиях кабинет срочно разработал компромиссный билль о создании государственной нефтегазовой корпорации «Петро-Канада» без привлечения частных инвесторов (требование НДП) и без национализации (требование официальной оппозиции). В экстренном телевизионном обращении к согражданам глава кабинета охарактеризовал билль как органическую часть новой энергетической политики. Расчеты правительства на симпатии электората оказались верными. Еще не прошедший первого чтения билль о «Петро-Канаде» получил поддержку $65 \%$ опрошенных канадцев. В Палате общин билль стал статутом на основе консенсуса - против «Петро-Канады» не проголосовал ни один депутат ${ }^{16}$.

Широкомасштабные действия кабинета меньшинства в энергетической отрасли стали достижением федеральной власти, имевшим многоплановые последствия. Канадские потребители и предприниматели нересурсных секторов экономики были избавлены от огромных дополнительных расходов на горючее и отопление жилищ. Замораживание внутренних нефтегазовых цен дало возможность федеральной власти с большим, чем ранее, успехом сдерживать рост цен на товары и услуги. Введение экспортной пошлины принесло федеральной казне дополнительный источник дохода, позволивший препятствовать разрастанию бюджетного дефицита. Признание парламентскими партиями принципа прямого участия федеральной власти в прибыльном нефтегазовом секторе создало прецедент, необходимый для укрепления экономического суверенитета страны в партнерстве со США, причем этому укреплению была обеспечена массовая поддержка электората.

\footnotetext{
${ }^{15}$ Обоснованием стала ссылка на статью 91-ю Конституции, закрепляющей право федеральной власти законодательствовать «в интересах поддержания мира, порядка и хорошего управления по всем вопросам, не отнесенным непосредственно к предметам исключительной компетенции провинций» (Canada. Department of Justice. Constitution Acts $1867-1982$. P.26 ).

${ }^{16}$ В дальнейшем «Петро-Канада» была сделана одной из крупнейших в Западном полушарии корпораций публичного права. Подробнее см.: Данилов С.Ю. Конституционная экономика зарубежных стран. М.: ГУ ВШЭ, 2008; Tupper A., ed. Public Corporations and Public Policy in Canada. Montreal, 1999.
}

В обстановке отраслевого кризиса правительство меньшинства не только не утратило власти, но и действовало вполне адекватно государственным интересам. Отводя мало отвечавшие традициям североамериканского социума предложения новых демократов, оно тем не менее сохраняло коалицию. В вопросе о правомерности государственного регулирования рынка нефтепродуктов правительство нашло равнодействующую между интересами потребителей, национального капитала обрабатывающего сектора и транснационального капитала.

После создания «Петро-Канады» кабинету пришлось решать вопрос о перераспределении доходов от продажи нефти и газа между центром и провинциальными властями, которые по конституции являются собственниками природных ресурсов. Образовался контраст между бурным ростом федеральных расходов и бесконтрольным увеличением доходов периферийных нефтедобывающих субъектов, которые в собственных интересах повысили арендные платежи нефтегазовой отрасли. На доходах центра это сказалось отрицательно, ибо в силу конвенций бизнесу при уплате федеральных налогов полагался вычет на всю сумму провинциальных арендных платежей. Между тем правительства нефтедобывающих провинций - Альберты и Саскачеван, недовольные замораживанием внутренних цен, намеревались обжаловать действия Оттавы в судах, а против остальных провинций применить «экономические санкции». Раздавались угрозы перейти к экспорту энергоносителей в обход федеральной власти. Выражение:«Мы заставим Восток мерзнуть в темноте» отражало настроения нефтяного бизнеса, местных властей и значительной части населения Канадского Запада. Не меньшим было ответное возмущение общественности Центральных и Восточных провинций, в которых западноканадских провинциальных премьеров сравнивали с корыстными ближневосточными шейхами.

Очередной компромисс был достигнут кабинетом меньшинства к шестому

месяцу кризиса в ходе практически непрерывных федерально-провинциальных конференций (ФПК). Федеральные доходы от экспортной пошлины были переадресованы в целевом порядке на нужды перерабатывающей промышленности нефтедобывающих провинций. Замораживание внутренних цен на энергоносители кабинет заменил более гибким средством регулирования - долгосрочным контролем над ценообразованием. Кабинет добился согласия властей западных провинций и бизнеса на повышение внутренних цен не чаще раза в 12 месяцев и на отказ от принципа вычета провинциальных платежей из федеральных налогов. Указанные провинции сняли возражения против свертывания экспорта нефти и газа, поддержали общеканадскую долгосрочную «программу экономии энергии» - корректировку промышленных и строительных стандартов, переход на ресурсосберегающие технологии и др.

Незначительную ранее долю Оттавы в общем объеме нефтегазовой ренты (3\%) кабинету меньшинства удалось увеличить в шесть раз - до $18 \%$ против $40 \%$ у провинций и $42 \%$ у бизнеса. То, что соглашение о разделе доходов имело форму не парламентского статута, а постановления ФПК, не умаляло обязывающей силы последнего, базирующегося на конституционных конвенциях. Перераспределение нефтегазовой ренты впервые за несколько десятилетий пополнило 
DOI: $10.7256 / 1811-9018.2014 .12 .13431$

При цитировании этой статьи сноска на dоі обязательна

\section{Право и политика $12(180) \cdot 2014$}

«общее право» страны прецедентом в пользу федерального центра, а не провинций.

В ходе переговоров кабинет меньшинства опирался на поддержку общественности и правительств провинций Центральной и Восточной Канады. Притязания Альберты и Саскачевана на расширительное толкование провинциальных прав и на подтягивание внутренних цен к уровню мировых отказались поддержать власти не только семи прочих англоязычных провинций, но и Квебека, обычно находящегося в оппозиции к любым действиям федеральной власти ${ }^{17}$. Заинтересованность в недорогом топливе и горючем оказалась сильнее всех других соображений. В нужный кабинету меньшинства момент сыграли положительную роль также его налогово-амортизационные преференции, оказанные обрабатывающему сектору нересурсных провинций. Альберта и Саскачеван не сочли в итоге целесообразным ни применение экономических санкций, ни оспаривание в судебном порядке «неправомерных», по их мнению, действий федерального центра в лице кабинета меньшинства, вокруг которого сплотилось восемь провинций из 10.

Благодаря тщательно спланированной и гибкой политике кабинета меньшинства Канада извлекла из энергетического кризиса выгоды. Действие имманентно присущих канадскому федерализму дезинтеграционных процессов было ослаблено, интересы потребителей и обрабатывающего сектора ограждены. Исторически сложившаяся уязвимость канадской топливно-сырьевой экономики не стала непреодолимой помехой тому, что позиции страны вследствие действий Оттавы были на континентальном и глобальном энергетическом рынке упрочены, а влияние Канады в международном сообществе возросло.

Правительство меньшинства нашло возможности провести в жизнь и другие меры к защите государственных интересов и суверенитета страны.

Подчиненность Канады старшему партнеру - США не воспрепятствовала принятию Парламентом по настоянию кабинета Закона о контроле над иностранными инвестициями, от принятия которого ранее уклонялось правительство большинства. Этот статут 1974г., одобренный Палатой общин единогласно, синтезировал идеи экономического суверенитета страны с нормами антимонопольного законодательства. Он наделил федеральную власть правом запрещать покупку канадских фирм иностранными предпринимателями. На потенциальных покупателей статут возложил бремя доказывания «ощутимой выгоды», которую предлагаемая ими сделка принесет Канаде в виде роста производительности труда, расширения переработки сырья, повышения качества товаров и услуг, сохранности природы и т.д. Компетенция созданного при Министерстве промышленности контрольно-надзорного Агентства распространялась на все сферы экономики и культуры, причем введенные ранее лимиты иностранной собственности в «ключевых отраслях» сохранили силу.

В компетенции Агентства находилось порядка 10\% общего количества ежегодных покупок канадской собственности. Законность прежних приобретений сомнению не подвергалась. К тому же на практике Агентство утверждало большую часть заявок, что давало повод сторонникам суверенитета

${ }^{17}$ Russell P., ed. Leading Constitutional Decisions. Ottawa, 1998. P. 401.
Канады называть его «беззубым бумажным тигром», а статут 1974г. бесполезным. Но подобные оценки грешат упрощенностью. Процедура проверки совместимости сделки с интересами Канады была сделана законодателем закрытой, длительной (до 4 месяцев) и облагалась значительной пошлиной. Агентство рассматривало только те заявки, к которым прилагалась обширная информация о потенциальном покупателе - активах, пакетах акций, доходах, международных связях. Причин запрета Агентство не оглашало. Отсутствие ответа приравнивалось к запрету, который по данному статуту не может быть оспорен в судебном порядке.

Право федеральной власти на запрещение покупки канадских фирм иностранцами из разрозненных прецедентов предшествующего периода стало неотъемлемой частью статутного права федерации. Уведомительный порядок приобретения фирм был заменен разрешительным ${ }^{18}$. Поэтому количество иностранных предпринимателей, приобретающих канадские фирмы, ощутимо уменьшилось, что входило в намерения создателей Агентства.

О том, насколько назревшей была реализация данной меры, свидетельствовало скорое принятие аналогичных статутов тремя крупными субъектами федерации - Онтарио, Британской Колумбией и Саскачеваном ${ }^{19}$.

Целенаправленность и результативность действий кабинета меньшинства в сочетании с их легитимностью 20 существенно укрепили его политические позиции, сделали его авторитет в стране непререкаемым. Когда позже у рядовых канадцев исследователи спрашивали, помнят ли они кабинет1972-1974 годов, самый распространенный ответ звучал так: «Конечно, помним. Тогда правительство было отзывчивым. Оно понимало нас». Леворадикальная печать, недовольная всеми правительствами, тем не менее охарактеризовала рассматриваемый кабинет как «наилучший в канадской истории».

Со временем, однако, все более проявлялось действие факторов. ослаблявших коалицию изнутри. Правительству, многие деятели которого были связаны с элитарными общественными кругами, было нелегко взаимодействовать с социалистами, отражавшими требования массовых общественных движений. В НДП зрело недовольство тем, что кабинет реализует ее предложения в измененном виде и не в полном объеме. Фракция новых демократов на 19-м месяце коалиции выдвинула вотум недоверия правительству, который был поддержан консерваторами и одобрен Палатой общин. В соответствии с конституционными конвенциями роспуск Палаты и проведение внеочередных всеобщих выборов стали неизбежными. Выборы завершились убедительной победой либералов. Они вернули себе абсолютное большинство в Палате, тогда как все оппозиционные партии,

\footnotetext{
${ }^{18}$ Подробнее см.: Hale G. Canadian Federalism and the Challenge of North American Integration. New York, 2003.

${ }^{19}$ Под действие указанного статута подпадали только фирмы с числом занятых не менее 100 человек и с активами не менее 5 млн. долл., т.е. средние и крупные. Приобретение иностранцами предприятий малого бизнеса поэтому стало предметом регулирования провинциальными статутами.

${ }^{20}$ Совместимости всех действий кабинета меньшинства с конституцией, статутным и общим (прецедентным) правом не подвергла сомнению ни одна из оппозиционных парламентских и внепарламентских сил.
} 
ответственные за вынесение кабинету вотума недоверия, понесли серьезные потери.

В свете всего сказанного напрашивается вывод, что рассмотренное в статье правительство менее чем за 600 дней сумело провести в жизнь целый комплекс назревших и популярных экономических и социально-политических мероприятий реформаторского характера. Оно изощренно пользовалось шкалой правовых источников семьи «общего права»: конституционными конвенциями, актами статутного права, парламентскими резолюциями, актами делегированного законодательства. Поражает продуманность и рациональность подавляющего большинства действий кабинета. Они позволили расширить массовый платежеспособный спрос, стимулировав производство товаров и услуг, сделать более доступной систему социального страхования, увеличить действенность региональной экономической помощи без заметного увеличения расходов на нее. Были созданы важные прецеденты государственного регулирования топливноэнергетического сектора. Законодательство о предвыборных расходах покончило с отсутствием юридической ответственности партий, закрепило в регулировании финансирования избирательного процесса режим гласности и отчетности, без которых немыслимо конституционное демократическое государство. Издание правительственного правила о «конфликте интересов» способствовало гораздо более действенному, чем ранее, разграничению политической и частнопредпринимательской деятельности. Получила развитие находившаяся в зачатке регламентация деятельности иностранного капитала, что упрочило суверенные права Канады в экономической сфере и расширило поле самостоятельных действий страны в экономическом комплексе Северной Америки.

Большинство актов правового регулирования, введенных в действие кабинетом меньшинства, сохраняет силу до сих пор, несмотря на многократные изменения экономической и политической ситуации в последние десятилетия.

Опыт данного правительства меньшинства и его наследие побуждают рассматривать достоинства и недостатки системы парламентского правления главным образом в позитивном ключе. Приведенный выше фактический материал убеждает, что качество государственного управления в конституционном демократическом государстве вполне может возрастать пропорционально препятствиям, которые правительству приходится преодолевать при формировании и в практической деятельности.

Конструктивный вклад указанного правительства парламентского меньшинства в развитие канадского общества и государства приходится признать объемным. И вклад был сделан вопреки неблагоприятным факторам, среди которых неизбежно фигурировали органически присущие парламентскому государству качества - неустойчивое положение кабинета, его зависимость от малой партии с иной социально-политической природой, неминуемые трения между партнерами по коалиции и как следствие - неопределенность перспектив существования правительства.

\section{Библиография:}

1. Богдановская И.Ю. Закон в английском праве. М.: Наука, 1987.

2. Богдановская И.Ю. Прецедентное право. М.: Наука, 1993.

3. Данилов С.Ю. Конституционная экономика зарубежных стран. - М.: ГУ ВШЭ, 2008

4. Данилов С.Ю. Эволюция канадского федерализма. - М.: Издательский дом НИУ ВШЭ, 2012.

5. Чиркин В.Е. и др. Сравнительное конституционное право. Монография.-М.: Манускрипт, 2002.

6. Campbell D., ed. Legal Aspects of Doing Business in North America. Minneapolis: Western Publishers, 1997.

7. Hodgins B. Where Constitution and Economy Meets in Canada. Toronto: C.D. Howe Institute, 1992.

8. Hogg P. Constitutional Law of Canada. Toronto: Carswell, 2007.

9. Russell P., ed. Leading Constitutional Decisions. 5th ed. Ottawa: Carleton Univ. Press, 1998

10. Smart W., ed. Studies in Crisis Management. Montreal: Institute for Research on Public Policy, 1990.

11. Stevenson G. Unfulfilled Union. Canadian Federalism and National Unity. Toronto: Gage, 2004.

12. Tierney M. Constitutional Law and National Pluralism. Oxford: Oxford Univ. Press, 2005. 14. Trudeau P. Memoirs. Toronto: McClelland and Stewart, 2001. 15. Tupper A., ed. Public Corporations and Public Policy in Canada. Montreal: Institute for Research on Public Policy, 1999.

\section{References (transliterated):}

1. Bogdanovskaya I.Yu. Zakon v angliiskom prave. M.: Nauka, 1987.

2. Bogdanovskaya I.Yu. Pretsedentnoe pravo. M.: Nauka, 1993.

3. Danilov S.Yu. Konstitutsionnaya ekonomika zarubezhnykh stran. - M.: GU VShE, 2008.

4. Danilov S.Yu. Evolyutsiya kanadskogo federalizma. - M.: Izdatel'skii dom NIU VShE, 2012.

5. Chirkin V.E. i dr. Sravnitel'noe konstitutsionnoe pravo. Monografiya.-M.: Manuskript, 2002.

6. Campbell D., ed. Legal Aspects of Doing Business in North America. Minneapolis: Western Publishers, 1997.

7. Hodgins B. Where Constitution and Economy Meets in Canada. Toronto: C.D. Howe Institute, 1992.

8. Hogg P. Constitutional Law of Canada. Toronto: Carswell, 2007.

9. Russell P., ed. Leading Constitutional Decisions. 5th ed. Ottawa: Carleton Univ. Press, 1998.

10. Smart W., ed. Studies in Crisis Management. Montreal: Institute for Research on Public Policy, 1990.

11. Stevenson G. Unfulfilled Union. Canadian Federalism and National Unity. Toronto: Gage, 2004.

12. Tierney M. Constitutional Law and National Pluralism. Oxford: Oxford Univ. Press, 2005. 14. Trudeau P. Memoirs. Toronto: McClelland and Stewart, 2001. 15. Tupper A., ed. Public Corporations and Public Policy in Canada. Montreal: Institute for Research on Public Policy, 1999. 